\section{Orvosi felügyeletet igénylö táplálásterápiás intervenció a háziorvosi gyakorlatban}

Molnár Andrea dr., PhD', Vajer Péter dr., PhD

'Magyar Dietetikusok Országos Szoovetsége, Tudományos Bizottság

Semmelweis Egyetem, Általános Orvostudományi Kar, Családorvosi Tanszék

A COVID-19 betegségnél prognosztikus tényező az időskor és a multimorbiditás mellett a malnutríció és a sarcopenia is. Mivel a malnutríciós betegek közel $90 \%$-a az otthonában tartózkodik, és a malnutríció független prediktora a mortalitásnak (OR: 7,00 ), ezért a járóbeteg-ellátás során a kezelések szerves részét képezi az orvosi felügyeletet igénylő táplálásterápia is. A cikk a COVID-19-es betegeken végzett beavatkozásokat összegzi, kifejezetten a kórházon kívül tartózkodó páciensek ellátására.

KULCSSZAVAK: malnutríció, sarcopenia, táplálásterápiás intervenció COVID-19-betegeknél

\section{Nutritional intervention requiring medical supervision in general} practice

Old age and multimorbidity, malnutrition and sarcopenia are also prognostic factors in COVID-19 disease. As nearly $90 \%$ of malnutrition patients are in their homes and malnutrition is an independent predictor of mortality (OR: 7.00), medical nutritional therapy must be an integral part of the treatment during outpatient care. The article summarizes the intervention of COVID-19 patients specifically for individuals with or recovering from COVID-19 in the community.

KEYWORDS: malnutrition, sarcopenia, intervention with medical nutrition therapy in COVID-19 patients

\section{Bevezetés \\ A háziorvosi gyakorlat során - a COVID-19 akut vírusfer- tôzés időszakában a poszt-COVID-szindróma fennálása esetén és a rehabilitáció ideje alatt is - a kóros tápláltsá- gi állapotokat (pl. malnutríció, sarcopenia, sarcopen obe- sitas, elesettségi szindróma) mint a betegség kimenetelét jelentősen rontó, a rehabilitációs folyamatot lassító, a mor- talitást szignifikánsan növelő tényezőket vesszz̈k figye- lembe, ezért a szürése és a kezelése az alapkezelés fontos részét képezi (1-3). \\ Kóros tápláltsági állapotok \\ A víruspandémia előtt a kóros tápláltsági állapotú betegek hozzávetőlegesen 8-10\%-a kórházban vagy idősek ottho- sült Királyságban folytatott kutatás szerint a malnutríiciós betegek 93\%-a az otthonában tartózkodott) (4). Hazánkban 2021-ben, a pandémia második hulláma alatt valószínüleg}

Central European Journal of Gastroenterology and Hepatology ez az arány eltolódott ugyan a kórházi tartózkodás irányába viszont a malnutríciós betegszám növekedése mellett az otthon tartózkodó malnutríciósak száma jelentősen emelkedett. Ezért is annyira fontos a háziorvosi és a szakambulanciai ellátás során a veszélyezetetett betegek kiszürése kiemelése, és az intervenció mielőbbi megkezdése. továbbá emeli a kórházi beutalások és a gyógyszerfelíások számát is. A malnutríciós betegek ellátásának költsége kétszeres a nem malnutríciós betegekéhez viszonyítva (4). Mortalitás szempontjából, független prediktornak tekinthetố a malnutríció (OR: 7,00); az életkor (10 évenként OR: $10,46)$ ) és a Charlson Comorbidity Index értéke (értékenként OR: 1,24) (4). Például influenzafertőzések esetén a mortalitás esélyhányadosa malnutríció fennállása esetén jelentősen megemelkedik (OR: 25,0) összehasonlítva pl. a kórházban szerzett fertőzésekkel (OR: 12,2) (4).

A COVID-1 9 betegség esetén rosszabb kimenetelre és magasabb mortalitásra lehet számítani az idős, a polimorbid
A családorvosi ellátás során a malnutríció kétszeresére növeli a konzultációk számát, hétszeresre a mortalitást táblázat: Kóros tápláltsági állapotok prevalenciája, a kórházba felvett CoVID-19-betegeknél $(3,6,9)$

\begin{tabular}{|c|c|c|c|c|}
\hline $\begin{array}{l}\text { Elöfordulási } \\
\text { gyakoriság }\end{array}$ & $\begin{array}{l}\text { Diagnosztizált } \\
\text { kóros táplältsági } \\
\text { állapot vagy a } \\
\text { rizikója }\end{array}$ & $\begin{array}{l}\text { Szürési } \\
\text { módszzer }\end{array}$ & $\begin{array}{l}\text { Betegszám, } \\
\text { életkor }\end{array}$ & Referencia \\
\hline $42 \%$ & $\begin{array}{l}\text { Malnutríció } \\
\text { (moderált: 23,7\%, } \\
\text { súlyos: } 18,4 \% \text { ) }\end{array}$ & $\begin{array}{l}\text { GLIM- } \\
\text { kritériumok }\end{array}$ & $\begin{array}{l}\mathrm{n}=114 ; \\
\text { átlagéletkor: } \\
67,5 \pm 15,5 \text { év }\end{array}$ & $\begin{array}{l}\text { Bedock D, et al. Prevalence and severity of } \\
\text { malnutrition in hospitalized COVID-19 } \\
\text { patients. Clin Nutr ESPEN. 2020; 40: 214-9. }\end{array}$ \\
\hline $80 \%$ & $\begin{array}{l}\text { A malnutríció } \\
\text { szempontjából } \\
\text { veszélyeztetett } \\
\text { (együtt a diag- } \\
\text { nosztizált malnut- } \\
\text { ríciós [52,7\%] és } \\
\text { a magas rizikójú } \\
\text { [27,5\%] betegek) }\end{array}$ & MNA & $\begin{array}{l}\mathrm{n}=182 ; \\
>65 \text { év } \\
\text { átlagéletkor: } \\
68,5 \pm 8,8 \text { év }\end{array}$ & $\begin{array}{l}\mathrm{Li} \text { T, et al. Prevalence of malnutrition and } \\
\text { analysis of related factors in elderly patients } \\
\text { with COVID-19 in Wuhan, China. Eur J Clin } \\
\text { Nutr. 2020; 74(6): 871-5. }\end{array}$ \\
\hline $73 \%$ & $\begin{array}{l}\text { Sarcopenia ma- } \\
\text { gas rizikója }\end{array}$ & SARC-F & $\begin{array}{l}\mathrm{n}=407 \text {; } \\
\text { átlagéletkor: } \\
64,8 \pm 14,2 \text { év }\end{array}$ & $\begin{array}{l}\text { Nicolette J W, et al. Poor nutritional status, } \\
\text { risk of sarcopenia and nutrition related comp- } \\
\text { laints are prevalent in COVID-19 patients } \\
\text { during and after hospital admission. Clinical } \\
\text { Nutrition ESPEN 2021. }\end{array}$ \\
\hline
\end{tabular}

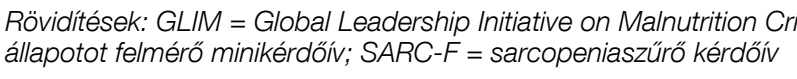

betegek mellett a malnutríciós személyeknél is. A komorbiditás jelentősen befolyásolja a mortalitást (pl. krónikus vesebetegségnél OR: 5,3; sziv-ér rendszeri betegségeknél OR: 3,9; agy-ér rendszeri betegségeknel OR: 3,9; COPD OR 3,7 ; magas vérnyomás OR: 2,7 ; tumorok OR: 2,6 ; diabétesz OR: 2,5; immunhiányos állapot OR: 1,6) (5). A kóros tápláltsági állapot kialakulása szempontjából fokozott figyelme igényelnek az idős, 65 év felettiek (6).

Hollandiában Wierdsma és munkatársai egy prospektív megfigyeleses vizsgalat során megállapitották, hogy a

kórházban tartózkodó COVID-19-betegek csoportjában magas (70\%-os) volt a sarcopenia rizikója, és már a kórház felvételkor jelentōs testtömegvesztéssel érkeztek a betegek az intézmenybe (minden 5. beteg) (3). Mivel a hosszas kórhazzi tartozzkodás során tovább romolhat a tápláltsági állapotuk (különösen az intenziv terápiás ellátásra szorulóké), igy azok, akik túlélik a betegséget, nagy valószínüséggel súlyos malnutrícióval és sarcopeniával érkeznek majd haza, ahol már a háziorvos feladata lesz a kóros tápláltsági

2. táblazzat: Orvosi felügyeletet igenylő táplálásterápiás intervenció a kơrházon kívül tartózkodó

\begin{tabular}{|c|c|c|}
\hline $\begin{array}{c}\text { Vizsgált } \\
\text { szempontok }\end{array}$ & Ajánlások & Megjegyzés \\
\hline Energiaigény & - 27-30 kcal/ttkg/nap & • >30 alultápláltság esetén \\
\hline Fehérjeigény & - $1 \mathrm{~g} / \mathrm{ttkg} / \mathrm{nap}$ & - $\geq 1,2 \mathrm{~g} /$ ttkg polimorbiditás, sarcopenia esetén. \\
\hline ONS & 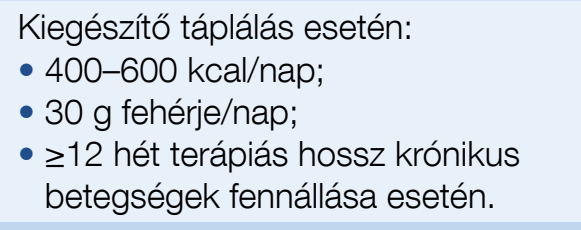 & $\begin{array}{l}\text { - Diabetes mellitus komorbiditás esetén cukorbete- } \\
\text { geknek kifejlesztett termékek javasoltak. } \\
\text { - Volumenintolerancia, illetve csökkent beteg- } \\
\text { együttmúködés esetén a magas tápanyagdenzitá- } \\
\text { sú, kis napi volumenú termékek javasoltak. }\end{array}$ \\
\hline Dysphagia & $\begin{array}{l}\text { - Enyhe és közepes dysphagia ese- } \\
\text { tén módosított textúrájú étrend (a } \\
\text { dysphagia gyakori a posztintubáci- } \\
\text { ós állapotokban). }\end{array}$ & $\begin{array}{l}\text { - Neurológiai kórkeppekkel társuló állapotoknál az } \\
\text { amilázrezisztens tulajdonságú súritópor biztonsá- } \\
\text { gosabb a keményitóalapú sưritéseknél. }\end{array}$ \\
\hline Szondatáplálás & $\begin{array}{l}\text { - Súlyos dysphagia esetén, vagy ha } \\
\text { per os nem biztositható az energia- } \\
\text { igény, szondatáplálás szükséges. }\end{array}$ & $\begin{array}{l}\text { - Diabetes mellitus komorbiditás esetén cukorbete- } \\
\text { geknek kifejlesztett szondatermékek javasoltak. } \\
\text { - Magyarországon elérhetó szondatáplált betegek } \\
\text { gondozására szakosodott otthonápolási szolgálat. }\end{array}$ \\
\hline
\end{tabular}

és tapasztalata. 
lásterápia hatékonyságának követése. Ideális esetben a malnutríció rizikójának felmérését az asszisztens végzi, a részletes tápláltsági állapot felmérését a dietetikus (ha elérhetö a praxisban), a kezelés és a követés pedig teammunkában történik.

\section{Orvosi felügyeletet igénylő táplálásterápia}

Cawood és munkatársai 15 publikációt (8 szakmai irányelvet, 4 ajánlást, 1 konszenzust, 1 összefoglalót és 1 riportot) áttekintve készítettek egy összefoglaló tanulmányt a COVID-19-betegek malnutríciójának szüréséről és a táplálásterápiájáról kórházon kívül (7). Az akut betegségre vagy zőkben foglalták össze (7):

3. táblázat: Segédlet a személyre szabott termékválasztáshoz

\begin{tabular}{|c|c|c|}
\hline Vizsgált szempontok & $\begin{array}{l}\text { Per os fogyasztható } \\
\text { termékek }\end{array}$ & $\begin{array}{l}\text { Szondatáplálásra } \\
\text { alkalmas termékek }\end{array}$ \\
\hline \multicolumn{3}{|l|}{ Betegigények } \\
\hline $\begin{array}{l}\text { Normál energia- és kiegyensúlyozott tápanyagösszetétel-igény, } \\
\text { normál volumentoleranciával }\end{array}$ & $\checkmark$ & $\checkmark$ \\
\hline $\begin{array}{l}\text { Normál energia- és kiegyensúlyozott tápanyagösszetétel-igény, } \\
\text { csökkent volumentoleranciával }\end{array}$ & & $\checkmark$ \\
\hline $\begin{array}{l}\text { Magas energia- és kiegyensúlyozott tápanyagösszetétel-igény, } \\
\text { normál volumentoleranciával }\end{array}$ & $\checkmark$ & $\checkmark$ \\
\hline $\begin{array}{l}\text { Magas energia- és kiegyensúlyozott tápanyagösszetétel-igény, } \\
\text { csökkent volumentoleranciával }\end{array}$ & $\checkmark$ & $\checkmark$ \\
\hline Magas fehérjeigény & $\checkmark$ & $\checkmark$ \\
\hline Tápanyagmodul-igény (fehérje, zsiŕ, szénhidrát, rost) & $\checkmark$ & \\
\hline Extenzíven hidrolizált fehérje iránti igény & $\checkmark$ & \\
\hline Aminosavigény & $\checkmark$ & \\
\hline Betegség/állapot & $\begin{array}{l}\text { Per os fogyasztható } \\
\text { termékek }\end{array}$ & $\begin{array}{l}\text { Szondatáplálásra } \\
\text { alkalmas termékek }\end{array}$ \\
\hline Diabetes mellitus/hyperglykaemia kiegyensúlyozott tápanyagigénnyel & $\checkmark$ & $\checkmark$ \\
\hline $\begin{array}{l}\text { Diabetes mellitus/hyperglykaemia magas energia- és magas } \\
\text { fehérjeigénnyel }\end{array}$ & $\checkmark$ & $\checkmark$ \\
\hline Gyulladásos bélbetegség & $\checkmark$ & \\
\hline Májbetegség & $\checkmark$ & $\checkmark$ \\
\hline Krónikus sebek (pl. decubitus) & $\checkmark$ & $\checkmark$ \\
\hline Emésztési és felszívódási zavarok & $\checkmark$ & $\checkmark$ \\
\hline Dysphagia & $\checkmark$ & \\
\hline Sarcopenia & $\checkmark$ & \\
\hline Tüdőbetegség & $\checkmark$ & \\
\hline Magas glutaminszükséglet & $\checkmark$ & \\
\hline Mútét elótti szénhidrátraktárak feltöltésére & $\checkmark$ & \\
\hline Veseelégtelenség & $\checkmark$ & \\
\hline Veseelégtelenség (dializálás alatt) & $\checkmark$ & \\
\hline Cisztás fibrózis & $\checkmark$ & \\
\hline Tejfehérje-allergia & $\checkmark$ & $\checkmark$ \\
\hline Többszörös táplálékallergia & $\checkmark$ & $\checkmark$ \\
\hline Ketogén diéta szükségessége pl. gyógyszerrezisztens epilepszia & $\checkmark$ & $\checkmark$ \\
\hline Anyagcsere-betegségek & $\checkmark$ & \\
\hline
\end{tabular}

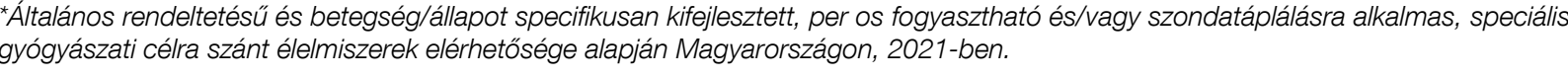

- Az első orvosi konzultáció alkalmával, majd minden további indokolt esetben szürni szükséges. Főleg a MUST (Malnutrition Universal Screening Tool) szürőmódszert Juvasoljäk, és felhiják a figye

A távoliknzultációk alkalmával is szükséges a szúrés (leA távoli konzultációk alkalm áva

- A malnutríciószürés eredményét dokumentálni kell majd a súlyosságtól függően kezelési tervet kell kidolA

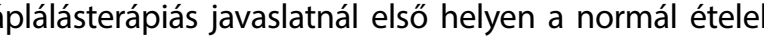
A (Az ONS - oral nutritional supplements - hazánkban megfelel a per os fogyasztható, speciális, gyógyászati célra szán (szerek, régi nevưkon tápszerek alkalmazásának.

Central European Journal of Gastroenterology and Hepatology

Volume 7, Issue 4 / December 2021
Az ONS kiegészitő táplásra történő alkalmazása esetén: - min. 400 kcal energia- és $30 \mathrm{~g}$ fehérjekiegészítés javasol elrendelni minimum 1 hónapon keresztü

- a dózis növelése és a terápiás idô meghosszabbítása javasolt:

- akut COVID-19-es betegeknél, amikor magas a malnutríció rizikója, vagy a kórházból hazatávozik a beteg ekkor az energiabevitel 600 kcal-ra való növelése javasolt;

- ha még krónikus betegség is fennál, akkor pedig a terápiahossz 12 hetes meghosszabbítása ajánlott.

Az ONS kiválasztásakor preferáltak a magas energia- és magas tápanyagdenzitású, szükség esetén a magas fehérjetartalmú termékek. Időseknél az előzőek mellett még megfontolandó, hogy mindez kis volumenterheléssel legyen biztosítható. Súlyos dysphagia esetén a betegekné szondatáplálást szükséges alkalmazni (7).

A hazai családorvosi gyakorlatban javasolt, de minőségbiztositási szempontból még nem elvárt a kóros tápláltsá gi állapotok (malnutríció, sarcopenia) rendszeres, validált módszerrel történő szürése és a súlyosság felmérése. Az orvosok sokkal inkább fizikális vizsgálattal (pl. vázizmok kitapintása, ökölszorító erő megítélése, bőr alatti zsírszövet csökkenésének észlelése), kikérdezéssel (pl. étvágy-, testtömegcsökkenésre vonatkozóan) és az árulkodó jelek megfigyelésével (pl. bő ruházat, szorosabbra húzott öv, lecsúszó gyürü, elvékonyodott bőr/haj) mérik fel a malnutríció és a sarcopenia rizikóját, és emelik ki a táplálásterápiára szoruló betegeket. A malnutríciós betegek kiszürésében segithetne az alultápláltság önszürési kérdőívének elterjedése és a sarcopenia rizikóját felmérō kérdőivek bevezetése, továbbá a telefonos konzultációk alkalmával az előzó kettő kérdéseinek feltétele.

A háziorvosi praxisban a táplálásterápia célja: a tápláltság állapot javitása (izomtömeg, izomerő megőrzése/javitása) a betegségek kedvezőbb kimenetelének támogatása, az

>Irodalom 1. Barazzoni R, Bischoff SC, Breda J, et al. ESPEN expert statements and
practical guidance for nutritional management of individuals with SARS-

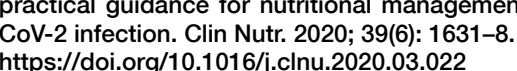
2. Cederholm T, Barazzoni R, Austin P, et al. ESPEN guidelines on definhttrs://doi.org/10.1016/j/clnu 2016.09.004 3. Nicolette J W, Hinke M K, Lotte AML K, et al. Poor nutritional status, risk of sarcopenia and nutrtition related complaints are prevalent in co-
VID-19 patients during and after hospital admission. Clinical Nutrition VID-19 patients
ESPEN 2021.

https:////oi.org/10.1016/j.linesp.2021.03.02

ing patients following a community-based diagnosis of malnutritition in the UK. Clin Nutr. 2011; 30(4): 422-9.
https://doi.org/10.1016/j): inu.2011.02.002

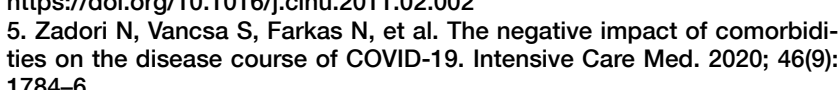

17ttps://doi.org/10.1007//500134-020-06161-9

6. Li T, Zhang $\mathrm{Y}$, Gong C, et al. Prevalence of malnutrition and analysis of
related factors in elderly patients with COVID-19 in Wuhan, China. Eur

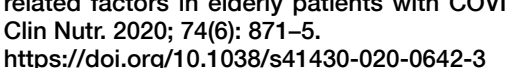

https://doioorgg/10.1038//541430-020-0642-3
7. Cawood AL, Walters ER, Smith TR, et al. A Review of Nutrition Support életminőség javítása és a függetlenség hosszú távú megorzése. Az esetek több mint a felénél a beteg szakorvos javaslattal erkezik a háziorvoshoz, és csak kisebb arányban Jortenik saját hatáskorben a táplálassterápia elrendelese Ekkor tipikusan 300-400 ml ONS-t írnak fel, 3-6 hónapra es az esetek közel 90\%-ában magas energia- és kiegyen súlyozott tapanyagtartalmú vagy cukorbetegeknek kifejlesztett termék elrendelése tortenik, es az esetek kb. 10\% ában várható az egyéb speciális készitmény felírása, min pl. krónikus sebekre vagy egyéb betegségre kifejlesztet termékek javaslata. beteg (8), így az ONS felírásánál, főleg időskorban, 10-ből $1-2$ alkalommal cukorbetegeknek kifejlesztett termékke tortenổ táplálásterápia javasolt. Amikor a cukorbetegséghez akut gyulladással járó kórkép társul (pl. COVID-19, (OPD, IBD), vagy bármi miatt magas a sarcopenia rizikója, vagy már diagnosztizálható a sarcopenia, vagy posztope rativ allapotban van a beteg, akkor a cukorbetegeknek kifejlesztett ONS-ek közül a magas fehérjetartalmú termék javasolt.

\section{Konklúzió}

A háziorvosi gyakorlatban - nemcsak a COVID-19, hanem egyéb akut és krónikus betegségek esetén is - bizonyitott, hogy a kedvezőbb kimenetelt és az életminőség javitását tekintve is szükséges a kóros tápláltsági állapo szempontjából a veszélyeztetett betegeket kiemelni, és mielöbb megkezdeni az orvosi felügyeletet igénylő táp allassterápiát. Az otthonában tartózkodó, malnutríció vagy sarcopenia miatt veszélyezetetett COVID-19-betegekné kiegészito táplálás esetén javasolt ONS-dózisok és a terá piás hossz a következő: kb. $30 \mathrm{~g}$ fehérje és kb. $600 \mathrm{kcal}, 12$ héten keresztül.

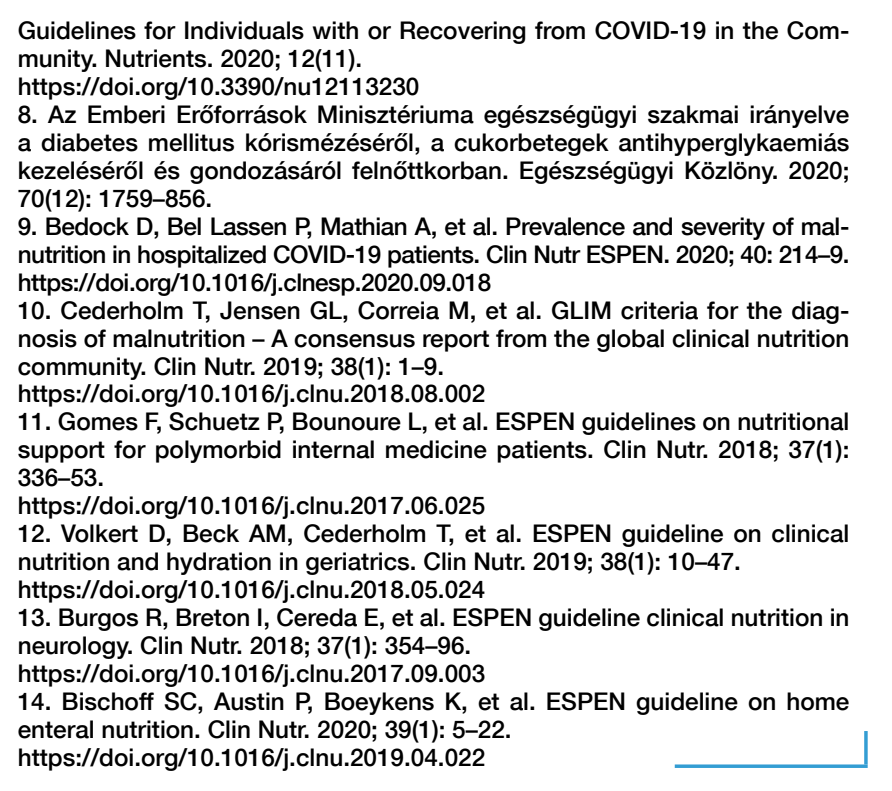

